\title{
Tragedy in Savar: Management of Victims in Enam Medical College Hospital
}

\author{
Mithun Alamgir ${ }^{1}$, Rukhsana Parvin ${ }^{2}$, Md. Aminul Haque Khan ${ }^{3}$ \\ Rceeived: November 1, 2013 Accepted: November 13, 2013
}

\begin{abstract}
Background: Rana Plaza collapse is the worst and deadliest man-made industrial disaster in the history of garment sector in the world. Around 1200 people died and thousands more were injured. Most of the victims of the disaster were treated in Enam Medical College Hospital (EMCH). We conducted this study to give an overview on the disaster victims and services provided by EMCH. Objective: The study was done to observe the length of time between accident and admission in EMCH, length of time between admission and discharge, to observe the numbers, types and sites of injuries to the victims, medical measures given to the victims and finally to observe the status of the victims at the time of discharge. Materials and Methods: This descriptive type of observational study was carried out among the victims of Rana Plaza tragedy during the period of May to October 2013. All admitted patients in EMCH were included in the study. Purposive nonprobability sampling technique was applied in this research work. Data were collected from the hospital record. After collection, data were manually compiled, edited and analyzed. Results: Among 621 victims treated in different wards, 276 (44.45\%) were admitted to the hospital on the day of accident. Among the admitted patients, 255 (41.06\%) stayed in the hospital for 1-3 days, 133 (21.42\%) for 4-7 days and 88 (14.17\%) for more than 10 days. Fracture and dislocation were present in $32.70 \%$ patients, lacerated injury in $18.20 \%$, abrasion in $15.78 \%$, bruise in $13.53 \%$, incised wound in $15.45 \%$ and punctured wound in $4.34 \%$ patients. Single injury was present in $56.68 \%$ and rest had multiple injuries. Lower limbs were the most (33.01\%) affected part of the body followed by head and neck (22.06\%), upper limbs (18.52\%), thorax (17.55\%) and abdomen (8.86\%). Two hundred seventy two patients (43.80\%) were improved after treatment and $56(9.02 \%)$ were fully cured; $23.83 \%$ of the victims were referred to higher medical centers for special measures. Conclusion: The collapse of Rana Plaza has fueled a greater call for reform and safety in garment industry. At the same time, all health care centers should adopt a broad-based approach to disaster-preparedness by providing a framework to ensure a well-coordinated response to mass casualty event.
\end{abstract}

Key words: Disaster, Injury, Rana Plaza, Garment sector

J Enam Med Col 2014; 4(1): 31-35

\section{Introduction}

Bangladesh, an export powerhouse, has more than 5,000 garment factories, handling orders for nearly all of the world's top brands and retailers. ${ }^{1}$ Garments sector generates $75 \%$ of the country's total export earnings. Currently an estimated 3.5 million workers are employed in these factories. ${ }^{2}$ Due to several unsafe conditions in these garment factories, numerous major accidents were reported before. But Rana Plaza incident is the most terrible industrial catastrophe which occurred on 24 April 2013 in

1. Associate Professor, Department of Community Medicine, Enam Medical College, Savar, Dhaka

2. Associate Professor, Department of Medicine, Enam Medical College \& Hospital, Savar, Dhaka

3. Professor, Department of Biochemistry, Enam Medical College, Savar, Dhaka

Correspondence Rukhsana Parvin, Email: rukhsana_parvin@yahoo.com 
Savar, Dhaka. Rana Plaza, a nine-storey building on Dhaka-Aricha highway, just two kilometers away from Enam Medical College, completely collapsed costing around 1200 lives, severely injuring thousands and missing an uncertain number of garments workers of different factories located in that plaza. In South Asia, this tragedy is just next to Bhupal disaster in India in 1984 in which 3787 persons succumbed to death because of tremendous gas explosion in Union Carbide India Limited. ${ }^{3}$ This tragedy is the world's deadliest garment industry disaster. ${ }^{4}$

Around 9 AM in the morning of April 24, 2013 the whole building collapsed. There were no signs of pillars and walls. The roofs fell one above the other. Thousands of workers became sandwiched between the roofs in different layers. Thousands of common people rushed to the spot to rescue the entrapped workers. Later on armed forces, rapid action battalion (RAB), police and firefighters joined the rescue operation. ${ }^{5}$

In this devastating and terrific situation, the nation as well as the whole world was overwhelmed by the exceptional unique service rendered by Enam Medical College \& Hospital (EMCH). The doctors, nurses, students and other staffs put their best efforts to save the lives of injured patients. They worked round the clock for almost a week without getting tired for a second. They created an incomparable example of humanitarian service.

Accident and Emergency department of the hospital was strengthened with extra manpower. Operation theaters were equipped with appropriate personnel and required equipments. All the wards of the hospital were made ready to receive the injured patients. After arrival in the college gate, the injured persons were immediately taken to the different service stations without any official formalities. Emergency department, operation theaters, wards, corridors, open spaces and all other places were either treatment or service stations. Every step was closely supervised by senior teachers and doctors. ${ }^{5}$

EMCH treated 1676 rescued injured victims. Among them 1028 persons were given primary treatment and 648 were admitted, including 27 in ICU. Admitted patients were given treatment for days, weeks and even months. EMCH alone had to bear the load of huge number of casualties as there is no such institution nearby. The disaster occurred during working period when all doctors, teachers and students were in the campus. ${ }^{5}$ For this reason, there were both skilled and non-skilled manpower who went into prompt action to manage such a big number of patients. As almost all sorts of medical services including full-fledged ICU, CCU, wellequipped operation theaters and modern investigation facilities (automated laboratory investigations, digital X-ray, CT, MRI and others) are available in this medical college, patients were diagnosed and managed quickly and appropriately. ${ }^{5}$

We conducted this study in EMCH to observe the length of time between accident and admission, length of time between admission and discharge, to observe the numbers, types and sites of injuries to the victims, medical measures given to the victims and finally to observe the status of the victims at the time of discharge.

\section{Materials and Methods}

This descriptive type of observational study was carried out among the victims of Rana Plaza tragedy in Savar, Dhaka, Bangladesh. The study was conducted in EMCH, Savar, Dhaka. The study area was purposively selected for convenience of data collection and to get adequate number of study population as most of the victims of this disaster were admitted in EMCH. Six hundred forty eight patients were admitted, including 27 in ICU. The study period was from May to October 2013.The study period included problem identification, topic selection, data collection, data analysis and writing of the report. Purposive nonprobability sampling technique was applied in this research work. All admitted patients in EMCH were included in the study. Six hundred twenty one patients admitted in different wards were the main subjects of this study, ICU patients are mentioned separately. Patients who died at the site of disaster or on way to hospital were excluded. After collection, data were manually compiled, edited and analyzed.

\section{Results}

Table I shows the length of time between the incident of Rana Plaza tragedy and admission to the hospital. Among 621 victims, 276 (44.45\%) were admitted to the hospital on the day of accident. Rest of the victims were taken to the hospital on subsequent 
days immediately after rescue. Table II shows that among the admitted patients, $255(41.06 \%)$ stayed in the hospital for 1-3 days, 133 (21.42\%) for 4-7 days and $88(14.17 \%)$ victims stayed in the hospital for more than 10 days.

Table I: Length of time between incident and admission $(n=621)$

\begin{tabular}{|c|c|c|}
\hline $\begin{array}{c}\text { Time between incident } \& \\
\text { admission }\end{array}$ & Frequency & Percentage \\
\hline 0 day & 276 & 44.45 \\
\hline $1-3$ days & 149 & 23.99 \\
$4-7$ days & 137 & 22.06 \\
$8-10$ days & 21 & 3.38 \\
$>10$ days & 38 & 6.12 \\
Total & 621 & 100 \\
\hline
\end{tabular}

Table II: Length of time between admission and discharge $(\mathrm{n}=621)$

\begin{tabular}{|c|c|c|}
\hline $\begin{array}{c}\text { Time between admission } \\
\& \text { discharge }\end{array}$ & Frequency & Percentage \\
\hline 0 day & 108 & 17.39 \\
\hline $1-3$ days & 255 & 41.06 \\
$4-7$ days & 133 & 21.42 \\
\hline 8-10 days & 37 & 5.96 \\
\hline 10 days & 88 & 14.17 \\
\hline Total & 621 & 100 \\
\hline
\end{tabular}

Table III shows that $203(32.70 \%)$ patients had fracture and dislocation and $113(18.20 \%)$ had lacerated injury. Rest of the victims had abrasion, bruise, incised and punctured wounds. Among 621 victims, $352(56.68 \%)$ had single injury in the body and rest had multiple injuries (Table IV). Lower limbs were the most affected part $(33.01 \%)$ of the body followed by head and neck (22.06\%), upper limbs $(18.52 \%)$, thorax $(17.55 \%)$ and abdomen $(8.86 \%)$ (Table V).

Table III: Types of predominant injuries of the victims $(n=621)$

\begin{tabular}{|l|c|c|}
\hline Types of injuries & Frequency & Percentage \\
\hline Abrasion & 98 & 15.78 \\
\hline Bruise & 84 & 13.53 \\
\hline Laceration & 113 & 18.20 \\
\hline Incised wound & 96 & 15.45 \\
\hline Punctured wound & 27 & 4.34 \\
\hline Dislocation and fracture & 203 & 32.70 \\
\hline Total & 621 & 100 \\
\hline
\end{tabular}

Table IV: Number of injuries of the victims $(\mathrm{n}=621)$

\begin{tabular}{|c|c|c|}
\hline Number of the injuries & Frequency & Percentage \\
\hline $0-1$ & 352 & 56.68 \\
\hline $2-3$ & 192 & 30.92 \\
\hline 3 & 77 & 12.40 \\
\hline Total & 621 & 100 \\
\hline
\end{tabular}

Table V: Sites of injuries of the victims $(n=621)$

\begin{tabular}{|c|c|c|}
\hline Sites of the injuries & Frequency & Percentage \\
\hline Head and Neck & 137 & 22.06 \\
\hline Thorax & 109 & 17.55 \\
\hline Abdomen & 55 & 8.86 \\
\hline Upper limb & 115 & 18.52 \\
Lower limb & 205 & 33.01 \\
\hline Total & 621 & 100 \\
\hline
\end{tabular}

Most of the admitted patients were managed by surgical or both surgical and medical measures. A few number of the injured patients were treated by medical measures only. Table VI shows that among 621 patients, $272(43.80 \%)$ were improved after treatment, $56(9.02 \%)$ were fully cured and 148 $(23.83 \%)$ of the victims were referred to higher medical centers for special medical measures.

Table VI: Physical condition of victims at the time of discharge $(n=621)$

\begin{tabular}{|c|c|c|}
\hline $\begin{array}{c}\text { Condition during } \\
\text { discharge }\end{array}$ & Frequency & Percentage \\
\hline Cured & 56 & 9.02 \\
\hline Improved & 272 & 43.80 \\
\hline No change & 139 & 22.38 \\
\hline Referred & 148 & 23.83 \\
\hline Died & 06 & 0.97 \\
\hline Total & 621 & 100 \\
\hline
\end{tabular}

Patients in ICU

In intensive care unit 27 patients were treated. Among them 15 were fully recovered, five patients died and seven were referred to higher medical centers for special management. 


\section{Discussion}

World Health Organization (WHO) defined disaster as any occurrence that causes damage, economic disruption, loss of human life and deterioration in health and the health services on a scale sufficient to warrant an extraordinary response from outside the affected community or area. Disaster may be natural or man-made. Several disasters occurred in different parts of the world at different times. Among the most remarkable disasters are the cyclone Sidr in Bangladesh in 2007, tsunami affecting Indonesia in 2004, collapse of twin tower of world trade center in New York in 2003, Bhupal toxic gas leakage in 1984, earthquake in Maharashtra in 1967 etc. Rana Plaza disaster, 2013 is a new addition to this list.

Every disaster has a unique set of circumstances in terms of etiology, environment, casualty load and medical resources available. ${ }^{6}$ After World Trade Center, Rana Plaza collapse is the second largest incident in the history of building collapse. It is the deadliest garment-factory accident in history and also the worst-ever accidental structural failure in modern human history. 7,8 According to the Bangladesh Garment Manufacturers and Exporters Association (BGMEA), around 3,122 workers were in the building at the time of the collapse. ${ }^{9}$ It was a big challenge for $\mathrm{EMCH}$ to face such a fatal tragedy.

Communication is an important component of disaster preparedness and response. A study on the response to three sequential aircraft crashes in Texas found communication as one of the major problems faced in the implementation of the community and hospital disaster plan. ${ }^{10}$ The length of time between onset of accident and admission is unpredictable in any given disaster, and usually not known because of breakdown in communications between the scene and hospital. ${ }^{11}$ In this present study, there was an effective communication between the hospital and the place of accident. The distance was two kilometers, road was straight and smooth and the density of traffic was very low as there was strike called by opposition political alliance. Immediately after the collapse, hospital authority sent ambulances and all other vehicles available in EMCH transport pool. The highest surge of patients $(276,44.45 \%)$ was on the first day which was attributable to this easy communication.

The readiness of healthcare facilities to respond to disasters has been at the center of public attention since September 11, 2001. ${ }^{12}$ Successful response of hospitals to the crisis requires coordination among all hospital units, planning and coordination of police, fire-fighting and pre-hospital emergency forces to establish communication lines and flexibility should be present for response according to extent and severity of incident. ${ }^{13}$ Effective triage is needed to screen out most of the noncritically injured survivors and should be done by a trained physician in the field. ${ }^{14}$

During the first few hours of Rana Plaza incident, there was no organized triage system. As a result, there was tremendous pressure of casualties in the hospital. A triage was formed in the emergency department in EMCH and patients were sorted out according to severity of injury and transferred to several departments to receive proper treatment. In this study, most $(203,32.70 \%)$ of the patients had fracture and dislocation followed by lacerated injury $(113,18.20 \%)$. Other victims had abrasion, bruise, incised and punctured wounds. Majority (352, $56.68 \%$ ) had single injury in the body and rest had multiple injuries. The most $(33.01 \%)$ affected parts of the body were lower limbs followed by head and neck $(22.06 \%)$, upper limbs $(18.52 \%)$, thorax $(17.55 \%)$ and abdomen (8.86\%).

Response of an institution to mass casualty involves the entire hospital. Even the non-medical personnel could help in simple interventions so that physicians could deal with the more critical patients. A study by Yasin et al revealed that the mobilization of medical students along with trained and untrained volunteers was very useful in their response efforts to the mass casualty from the Pakistani earthquake of 2005. ${ }^{15}$ But these should be supervised and guided, otherwise it could produce chaos that would be harmful to the response effort. ${ }^{16}$ During Rana Plaza disaster, all the medical students, office staffs and other non-skilled personnel of EMCH worked together under the supervision of teachers and consultants.

In a study by Einav et al, the importance of coordinated interaction between all area hospitals was emphasized to allow a later "secondary distribution" of casualties to the most appropriate facilities for definitive care and recovery. ${ }^{17}$ In this study, we found that $23.83 \%$ patients were referred to other specialized care centers for specific management. 
The duration of staying in hospital was 1-3 days in most of the patients $(41.06 \%)$. Length of stay depended upon the nature and severity of injury and also number of body regions involved. Lower limbs (33.01\%) were the most affected part of the body followed by head and neck $(22.06 \%)$. Most of the patients were managed by surgical or both surgical and medical measures. Inpatient death rate was only $0.97 \%$.

There was an important limitation in this study regarding record keeping. Often these were incomplete. Doctors had to manage a large number of patients within short period and so many important documents remained unrecorded. Good record keeping is necessary for continuity of care, avoidance of duplication of efforts and also allows a retrospective analysis of the response effort. ${ }^{18}$

According to Frykberg, experience from an actual event is the only reliable way for preparation and implementation of unique elements of disaster response as true mass casualty incidents are rare. ${ }^{11}$ To lessen the impact of disaster, resources and responsibilities should be organized and managed properly to deal with the humanitarian aspects of emergencies. ${ }^{19}$

The role of $\mathrm{EMCH}$ in management of these huge casualties was highly appreciated nationally and internationally. Hospitals can develop an effective disaster plan for future crisis management based on this unique experience. Lessons learnt can be incorporated in the institutional preparedness of the disaster response though it may need to be tailored according to the peculiarities of incident.

\section{Acknowledgement}

We greatly acknowledge the active support of Dr. Maksuda Pervin, Dr. Afzal Hossain. Dr. Tahmina Akter, Dr. Tasmia Ulfat, Lecturers, Department of Biochemistry, Enam Medical College, Savar, Dhaka, Dr. Jannatul Ferdous Honey, Dr. Gazi Salauddin and Dr. Fariha Fairuze, Internee doctors and Dr. Abdullah Al Shaurav, Indoor Medical Officer, Department of Medicine, Enam Medical College \& Hospital, Savar, Dhaka for collecting data from hospital records.

\section{References}

1. Yardley J. Report on deadly factory collapse in Bangladesh finds widespread blame. The New York Times, May 22, 2013.
2. Bangladesh fire and building safety agreement-November 2012. Published in International Labor Rights Forum, November 2012.

3. The Economist [Online version], May 2013.

4. The Daily Star, June 9, 2013.

5. Khan MAH, Parvin R, Alamgir M. Tragedy in Savar humanity in debris and unique role of Enam Medical College. J Enam Med Col 2013; 3(2): 60-62.

6. Frykberg ER, Tepas JJ. Terrorist bombings. Lessons learned from Belfast to Beirut. Ann Surg. 1988; 208(5): $569-576$

7. Bangladesh building collapse death toll passes 500. BBC News, May 3, 2013.

8. Bangladesh building collapse death toll tops 500; engineer whistleblower arrested. Huffington Post, May 3, 2013.

9. Case filed against owners of collapsed building in Dhaka. Avaiable at: http://www.itv.com/news/update/2013-0425/case-filed-against-owners-of-collapsed-building-indhaka. Accessed October 2013.

10. Klein JS, Weigelt JA. Disaster management. Lessons learned. Surg Clin North Am 1991; 71(2): 257-266.

11. Frykberg ER. Principles of mass casualty management following terrorist disasters. Ann Surg. 2004; 8(3): 319-321.

12. O'Neill PA. The ABC's of disaster response. Scand J Surg. 2005; 94(4): 259-266.

13. Zane RD, Prestipino AL. Implementing the hospital emergency incident command system: an integrated delivery system's experience. Prehosp Disaster Med. 2004; 19(4): 311-317.

14. Champion HR, Sacco WJ, Gainer PS, Patow SM. The effect of medical direction on trauma triage. J Trauma. 1988; 8: 235-239.

15. Yasin MA, Malik SA, Nasreen G, Safdar CA. Experience with masss casualties in a subcontinent earthquake. Turkish J Trauma Emerg Surg 2009; 8(5): 487-492.

16. Halpern P, Tsai M, Arnold JL, Stock E, Esroy G. Mass casualty, terrorist bombings: implications for emergency department and hospital response (Part II). Pre Hosp Dis Med 2003; 8(3): 235-241.

17. Einav S, Zvi F, Weissman C, Zaichik D, Caspi G, Kotler $\mathrm{D}$ et al. Evacuation priorities in mass casualty terrorrelated events: implications for contingency planning. Ann Surg 2004; 239: 304-310.

18. Hirschberg A, Stein M. Trauma care in mass casualty incidents. In: Feliciano DV, Mattox KL, Moore EE (eds). Trauma. $6^{\text {th }}$ edn. New York: McGraw-Hill; 2008: 141-155.

19. Disaster management. International federation of red cross and red crescent societies. Available at: http://www.ifrc.org/en/what-we-do/disaster-management/. Accessed October 2013. 